\title{
Model Desa di Masa Depan DAN KEBIJAKan PEMbinaAnNya
}

jurnal.kemendagri.go.id/index.php/ $\mathrm{mp}$

\section{e-ISSN: 2549-5283}

p-ISSN: 2549-5151

Matra Pembaruan 4 (1) (2020):

47-57

DOI:-

10.21787/mp.4.1.2020.47-57

Keywords:Village, public policy, competitiveness

Kata Kunci: Desa, kebijakan publik, daya saing

\section{*Korespondensi \\ Phone : +6281344506933 \\ Email : heriwahyudianto03@ gmail.com}

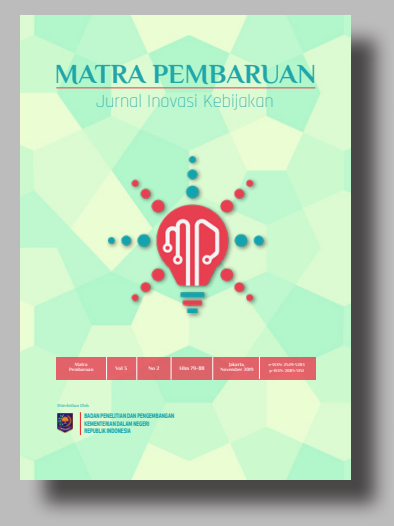

BADAN PENELITIAN DAN PENGEMBANGAN (BPP) KEMENTERIAN DALAM NEGERI

Jl. Kramat Raya No 132, Jakarta Pusat, 10450

(C)Heri Wahyudianto

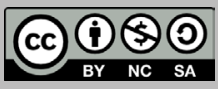

Karya ini dilisensikan di bawah Lisensi Internasional Creative Commons Atribusi Nonkomersial Sharealike 4.0.

\section{Heri Wahyudianto*}

Badan Penelitian dan Pengembangan Daerah Provinsi Papua Jl. Abe Pantai No. 26 Tanah Hitam Abepura Jayapura

Dikirim: 05 Februari 2020; Direvisi: 24 April 2020;

Disetujui: 29 April 2020

\begin{abstract}
The policy to determine the village model in Indonesia so far only refers to the village typology by referring to the characteristics of the village, so that the formation is also general and solely based on the characteristics of the village. Related to this, the focus of this study includes "new thinking" which aims to introduce the village model going forward based on the potential and problems faced by the village, to find more appropriate village models and their respective coaching policies. This study uses a qualitative approach with qualitative descriptive methods. In addition, this study is a literature study, so there are no study locations and also no informants or resource persons. The results of this study have formulated criteria that can be used to determine a village, namely village authority, basic infrastructure, facilities, and living conditions of village communities. The parameters are set as a percentage to determine the condition of a village. Various possible village models are based on these criteria and parameters. As for the priority development policies for each village whose model has been determined, the identification of village problems, village potentials, and regional characteristics (problems and potentials) must first be identified. Policy handling issues that are analyzed related to basic infrastructure facilities and village conditions and village communities. Meanwhile, regional potential development policies pay attention to superior potential, community-based potential, and small and medium potential.
\end{abstract}

\section{Intisari}

Kebijakan penentuan model desa di Indonesia selama ini hanya mengacu pada tipologi desa dengan merujuk pada karakteristik desa, sehingga pembinaannya pun bersifat umum dan semata-mata didasarkan pada faktor karaktertistik desa. Terkait denganhal itu, fokus kajian ini memuat "pemikiran baru" yang bertujuan mengenalkan model desa ke depan berdasarkan potensi dan permasalahan yang dihadapi desa, untuk menemukan model-model desa dan masing-masing kebijakan pembinaannya yang lebih tepat. Kajian ini menggunakan pendekatan kualitatif dengan metode deskriptif kualitatif. Selain itu, kajian ini merupakan studi pustaka, sehingga tidak ada lokasi kajian dan juga tidak ada informan atau narasumber. Hasil kajian ini telah merumuskan kriteria yang dapat dipakai untuk menentukan suatu desa, yaitu kewenangan desa, prasarana dasar, sarana, dan kondisi kehidupan masyarakat desa. Parameternya ditetapkan secara persentase untuk mengetahui baik buruknya kondisi suatu desa. Berbagai kemungkinan model desa berdasarkan pada kriteria dan parameter tersebut. Adapun untuk kebijakan prioritas pembinaan masing-masing desa yang telah ditetapkan modelnya, terlebih dahulu dilakukan identifikasi permasalahan desa, potensi desa, dan karakteristik daerah (permasalahan dan potensinya). Kebijakan penanganan masalah yang dianalisis terkait sarana dan prasarana dasar desa dan kondisi masyarakat desa. Sementara, kebijakan pengembangan potensi daerah memperhatikan potensi unggulan, potensi berbasis kemasyarakatakan, serta potensi kecil dan menengah. 


\section{Pendahuluan}

Eksistensi desa selalu menarik dan relevan untuk dikaji, terutama jika disorot dari sisi pembinaannya yang selama ini sangat bervariasi, namun tidak semua intervensi yang dilakukan telah berhasil memajukan desa. Salah satu hal yang menyebabkan demikian adalah persoalan penentuan model desa yang umumnya hanya mengacu pada tipologi desa dengan merujuk pada karakteristik desa, seperti desa pengunungan, desa perbatasan, desa persawahan, desa pesisir, desa swasembada, desa swadaya, dan lain-lain.

Memang, berbagai tipologi desa di atas memiliki kelebihan seperti dapat mengelola dan mengembangkan desa berdasarkan pada kondisi riil desa tertentu. Namun kekurangannya adalah hanya semata-mata didasarkan pada faktor karaktertistik desa tertentu, sehingga pembinaannya pun cenderung bersifat umum. Inilah keterbatasan atau masalah yang muncul dari tipologi yang ada selama ini. Sehingga, perlu ada tipologi desa yang baru, seperti yang ditawarkan kajian ini.

Penentuan model desa ke depan dalam kajian ini didasarkan pada potensi dan permasalahan yang dihadapi desa. Sementara kajian-kajian sebelumnya lebih fokus pada model pengembangan desa yang berbasis tertentu. Kajian-kajian sebelumnya yang dimaksud, misalnya, Rochman (2017) meneliti model desa yang hanya berbasis pada pemberdayaan masyarakat. Begitu juga dengan Subekti dan Damayanti (2019) yang mengembangkan model smart village yang merupakan turunan dari smart city. Penelitian Hilman dan Nimasari (2018) juga mengembangkan model program pemberdayaan masyarakat desa berbasis komunitas. Adapun Sugiyanto, Djana, dan Ismail (2016) mengajukan model desa berbasis kemitraan. Adapun Hasniati (2016) yang berfokus pada model akuntabilitas pengelolaan dana desa.

Idealnya, tujuan pembinaan desa adalah menunjukkan arah atau membawa pencerahan bagi masyarakat desa, membantu memecahkan masalah yang benar-benar riil dihadapi masyarakat desa, membantu mengurangi beban kehidupan masyarakat desa, serta menuntun 19 masyarakat desa ke arah kehidupan yang lebih sejahtera (Misra, 2016, p. 39).

Tujuan pembinaan desa berimplikasi pada urgensi pengembangan institusi, sumber daya manusia, ekonomi desa, teknologi desa, dan pembinaan kehidupan sosial di desa. Implikasi tersebut tidak hanya berangkat dari persoalan karakteristik desa saja, melainkan juga yang lebih pokok adalah persoalan penentuan model desa yang perlu didasarkan pada potensi dan permasalahan yang dihadapi desa terlebih dahulu melalui identifikasi yang tepat. Potensi lokal pedesaan merupakan komoditas yang patut dikembangkan karena berperan penting dalam mengangkat taraf hidup bangsa pada umumnya dan masyarakat desa pada khususnya (Aditiawati et al., 2016, p. 27).

Sebagai langkah awal, menentukan model desa perlu merumuskan model secara komprehensif dan terintegratif dengan memerhatikan pengelolaan lingkungan serta membangun hubungan yang harmonis antara manusia dan lingkungannya. Penentuan model desa sebaiknya dilakukan secara terpadu untuk melestarikan fungsi lingkungan hidup yang meliputi kebijaksanaan dalam hal penataan, pemanfaatan, pengembangan, pemeliharaan, pemulihan, pengawasan, dan pengendalian lingkungan hidup.

Penentuan model desa yang secara terencana perlu disesuaikan dengan tipologi desa yang unik seperti desa pesisir, desa persawahan, dan desa pegunungan atau berlahan kering (Aditiawati et al., 2016, p. 7). Belum lagi, potensi lokal dan karakteristik sosial budaya masyarakat yang beragam membutuhkan pendekatan dan pengelolaan yang berbeda pula disesuaikan dengan lokalitas mereka sehingga diterima dan mampu memberikan nilai manfaat bagi masyarakat setempat.

Model desa dalam pengembangan hasil penelitian terpadu, misalnya, dimaksudkan sebagai pengembangan dari hasil-hasil penelitian yang ada dan berupaya diaplikasikan pada masyarakat agar bermanfaat bagi peningkatan kesejahteraan masyarakat. Muaranya, mengurangi kemiskinan dan memberdayakan masyarakatsehingga mereka dapat mandiri (Marbun, 1977, p. 53). Selain itu, konsep dan model desa ini dapat dikombinasikan dengan penelitian dan pengabdian kepada masyarakat desa yang bersangkutan. Pengabdian yang dimaksud adalah proses kerja sosial yang mengedepankan kemanfaatan kegiatan untuk masyarakat di tingkat lokal. Dari konsep umum itulah, pemaknaan desa ditujukan untuk membantu memecahkan masalah yang dihadapi masyarakat desa, melalui inovasi yang memberikan pencerahan bagi masyarakat, dan mengurangi beban kehidupan masyarakat dengan lebih mensejahterakan mereka.

Dengan demikian, thesis statement yang dibangun dalam kajian ini adalah, bahwa "program desa harus bersifat mendidik dengan tolok ukur mengubah perilaku masyarakat sehingga mereka lebih berdaya dan mandiri." Kegiatan ini pun harus memberi contoh konkret (tidak abstrak), karena menekankan pada aksi. Pembinaan yang ada harus memotivasi dan memfasilitasi, serta mengembangkan potensi lokal. Kegiatannya pun harus mengutamakan partisipasi masyarakat. Untuk itu, pendekatan yang digunakan pada program desa binaan ini multi-disiplin ilmu; bersifat pragmatisrealistis; mengedepankan "problem solving"; serta dimulai dengan yang dibutuhkan dan diinginkan masyarakat dan melibatkan kepemimpinan lokal. 
Idealnya memanfaatkan institusi dan kelompokkelompok yang telah ada di masyarakat.

Dari elaborasi di atas, berdasarkan lokalitas dan konteks sosial budaya yang berbeda di masyarakat maka pertanyaan mendasar yang muncul adalah bagaimana konsep dan model desa yang strategis dalam pemberdayaan masyarakat termasuk di dalamnya proses pengelolaan lingkungan dilakukan. Kemudian, bagaimana manfaat positifnya baik bagi masyarakat maupun lingkungan sekitar. Atas dasar itu, perlu dilakukan identifikasi model desa berdasarkan potensi dan permasalahan yang dihadapi desa untuk menemukan model-model desa dan masing-masing cara pembinaannya yang lebih tepat.

Kajian identifikasi model desa ini memiliki maksud mendapatkan daftar model-model desa yang diindikasikan pada suatu daerah Kabupaten. Selain itu, kajian identifikasi tersebut bertujuan untuk memudahkan pemrograman pembinaan pada tahapan selanjutnya setiap model desa yang diindikasikan dalam daftar model desa. Adapun sasaran kajian identifikasi model desa ini adalah: (1) Tersusunnya daftar model-model desa sesuai dengan urutan prioritas yang berawal dari model desa paling tidak maju yang perlu segera ditangani; (2) Tersusunnya berbagai model desa; dan (3) Terstrukturnya pembinaan berbagai model desa sesuai prioritas.

\section{Metode}

Kajian ini menggunakan pendekatan kualitatif dengan metode dekriptif kualitatif. Kajian merupakan studi pustaka, sehingga tidak ada lokasi kajian dan juga tidak ada informan atau narasumber. Selain itu, Lokasi sasaran adalah desadesa di Indonesia yang digolongkan dalam beberapa tipologi, yaitu: desa maju, desa berkembang, dan desa tidak maju. Dasarnya adalah untuk memilah dalam pengidentifikasian potensi dan permasalahan yang dihadapi desa-desa pada ketiga tipologi tersebut. Sementara, kelompok sasaran adalah masyarakat dan lembaga yang ada di desa-desa tersebut.

Kajian juga dilakukan dengan dua arah pendekatan, yaitu: (1) Pendekatan perencanaan top-down. Pendekatan dari atas harus dilakukan terutama pada kegiatan review dan acuan kebijakan yang telah ditetapkan terkait dengan identifikasi model desa, dan (2) Pendekatan perencanaan bottom-up, yaitu konsep perencanaan dengan aspirasi yang muncul dari bawah. Pendekatan dari bawah harus dilakukan terutama pada kegiatan identifikasi karakteristik permasalahan dan potensi tiap kawasan pedesaan. Dengan demikian, maka gambaran karakteristik yang diperoleh merupakan hasil yang valid, akurat, dan sesuai dengan aspirasi masyarakat (Uphoff et al., 1979, p. 112).

Kemudian program pembinaan desa memerhatikan beberapa azas pembangunan yang merupakan acuan dasar pelaksanaan, yaitu: (1) Azas Manfaat, (2) Azas Berkeadilan, (3) Azas Berkelanjutan, (4) Azas Pemberdayaan Masyarakat Lokal, dan (5) Azas Komitmen Pemerintah Kabupaten (Tomasoa, 2017, p. 50). Selain itu, Kebijakan yang menjadi dasar dalam pelaksanaan program pembinaan desa antara lain: (1) Indentifikasi semua desa-desa dengan indikator unit administratif desa, (2) Meningkatkan aksesibilitas, keterkaitan, serta sarana dan prasarana desa dalam rangka mengeliminir ketidak majuan desa atau ketidak majuan desa, (3) Memberikan bantuan teknis sebagai stimulan untuk pengembangan desadesa yang berwawasan potensi lokal (spesifik), (4) Mengembangkan manajemen pembangunan desa secara terprogram, menyeluruh, berkelanjutan, dan partisipatif, sertabermuatan tridaya (pemberdayaan masyarakat, usaha, dan lingkungan), (5) Mengembangkan kapasitas institusi dan kesadaran pemerintah daerah, komunitas lokal, dan perangkat hukum yang baik dalam rangka tata pemerintah yang baik (good governance and management), dan (6) Menggerakkan dan mendorong terjadinya investasi pada desa-desa melalui kerjasama antara pemerintah, dunia usaha/swasta, dan masyarakat (Goldsmtih \& Blustain, 1980).

\section{Hasil Dan Pembahasan}

Baian iniakan menjelaskan beberapa hal seperti identifikasi model desa, identifikasi permasalahan dan potensi desa, kebijakan (skenario) pembinaan desa, strategi prioritas pembinaan desa, dan penyajian hasil identifikasi model desa.

\section{A. Identifikasi Model Desa}

Langkah-langkah identifikasi model desa "mengadaptasi" konsep model desa dari Aminah dan Susanto (2018), Pakaya (2016), dan Siagian (2003). Pertama, batasan. Dalam kajian ini, yang dimaksudkan dengan desa adalah kawasan perdesaan yang idealnya telah memiliki ketersediaan prasarana dasar dan sarana yang dapat menopang pertumbuhan atau perkembangan kehidupan masyarakat di desa, terutama dalam bidang ekonomi dan bidang pendidikan.

Kedua, kriteria. Atas dasar definisi yang ditetapkan itu, maka paling tidak ada 4 kriteria untuk menentukan (mengindikasikan) suatu desa. Pertama, daerah perdesaan. Pemerintahan desa memerlukan kewenangan dalam penyelenggaraannya, baik itu kewenangan yang bersifat asal usul maupun kewenangan atributif. Kewenangan-kewenangan tersebut bertujuan untuk mendorong prakarsa, gerakan, dan partisipasi masyarakat desa guna pengembangan potensi dan aset desa. Kewenangan desa dapat dilihat dari 3 (tiga) aspek, yaitu: (a) Apabila desa diberi 
kedudukan sebagai komunitas yang mengatur dirinya sendiri berdasarkan asal usul dan hak-hak tradisionalnya. Maka kewenangan yang dimiliki oleh desa adalah kewenangan asli berdasarkan asas rekognisi (pengakuan dan penghormatan); (b) Apabila desa ditempatkan sebagai "daerah otonom tingkat III", maka kewenangan desa adalah kewenangan yang "diserahkan" dari pemerintah, sesuai dengan asas desentralisasi; dan (c) Apabila desa ditempatkan sebagai unit pemerintahan, maka kewenangan desa adalah kewenangan yang "didelegasikan" oleh pemerintahan atasannya, sesuai asas dekonsentrasi atau tugas pembantuan. Delegasi berarti membentuk desa sebagai unit administratif seperti kelurahan. Dengan demikian, kriteria daerah pedesaan adalah unit administratif desa. Kedua, prasarana dasar. Prasarana dasar wilayah adalah kelengkapan dasar fisik wilayah yang memungkinkan wilayah dapat berfungsi sebagaimana mestinya. Dengan demikian, kriteria prasarana dasar desa adalah air bersih, listrik, dan irigasi. Ketiga, sarana. Kriteria prasarana desa adalah sarana ekonomi (pasar, pertokoan, PKL, dan industri), sarana sosial (kesehatan dan pendidikan), dan sarana transportasi (terminal, stasiun, dll.). Dalam konteks pembangunan desa, keberhasilan pembangunan desa tidak saja ditentukan ditentukan oleh kapasitas sumber daya manusia aparat pemerintah desa, melainkan juga sarana dan prasarana terutama sumberdaya keuangan desa dalam jumlah besar. Keempat, kondisi kehidupan masyarakat. Pengertian kondisi kehidupan masyarakat adalah cara (hal atau keadaan) hidup orang atau masyarakat sebagai makhluk sosial, termasuk berhubungan dengan aktivitasnya, mata pencaharian, dan keberlangsungan kehidupannya. Dengan demikian, kriteria kondisi masyarakat desa adalah: perekonomian masyarakat, pendidikan masyarakat, dan produkitivitas masyarakat.

Ketiga, instrumen penilaian. Penetapan penilaian untuk tiap kriteria dan parameternya dirumuskan seperti pada tabel 1 dan 2 di bawah ini (kriteria atau kategorisasinya mengacu pada kedua langkah tersebut di atas, sedangkan parameter dan penilaiannya mengacu pada Kementerian Negara Pembangunan Daerah Tertinggal. Keempat, rumusan model desa. Mengacu pada Tabel 1 di atas, maka tentunya terdapat rumusan berbagai kemungkinan model desa berdasarkan kriteria dan parameternya, seperti ditunjukkan pada Tabel 2 di bawah ini.

Berdasarkan Tabel 2 diatas, dapat dilihat, model desa A (desa yang ketersediaan prasarana dasar wilayahnya buruk, ketersediaan sarana wilayahnya cukup, dan kondisi kehidupan masyarakatnya baik); model desa B (desa yang ketersediaan prasarana dasar wilayahnya baik, ketersediaan sarana wilayahnya cukup, dan kondisi kehidupan masyarakatnya buruk); model desa C (desa yang ketersediaan prasarana dasar wilayahnya cukup, ketersediaan sarana wilayahnya buruk, dan kondisi kehidupan masyarakatnya baik); model desa D (desa yang ketersediaan prasarana dasar wilayahnya cukup, ketersediaan sarana wilayahnya baik, dan kondisi kehidupan masyarakatnya buruk); model desa E (desa yang ketersediaan prasarana dasar wilayahnya baik, ketersediaan sarana wilayahnya buruk, dan kondisi kehidupan masyarakatnya buruk): model desa F (desa yang ketersediaan prasarana dasar wilayahnya baik, ketersediaan sarana wilayahnya cukup, dan kondisi kehidupan masyarakatnya cukup); model desa G (desa yang ketersediaan prasarana dasar wilayahnya buruk, ketersediaan sarana wilayahnya buruk, dan kondisi kehidupan masyarakatnya buruk).

Selanjutnya model desa $H$ (desa yang ketersediaan prasarana dasar wilayahnya cukup, ketersediaan sarana wilayahnya cukup, dan kondisi kehidupan masyarakatnya cukup); model desa I (Desa yang ketersediaan prasarana dasar wilayahnya baik, ketersediaan sarana wilayahnya baik, dan kondisi kehidupan masyarakatnya baik); model desa J (Desa yang ketersediaan prasarana dasar wilayahnya cukup, ketersediaan sarana wilayahnya cukup, dan kondisi kehidupan masyarakatnya cuku); model desa K (Desa yang ketersediaan prasarana dasar wilayahnya buruk, ketersediaan sarana wilayahnya buruk, dan kondisi kehidupan masyarakatnya baik); model desa L (Desa yang ketersediaan prasarana dasar wilayahnya buruk, ketersediaan sarana wilayahnya buruk, dan kondisi kehidupan masyarakatnya cukup); Model Desa ........ dst.

\section{B. Identifikasi Permasalahan dan Potensi Desa}

Identifikasi juga dilakukan terhadap berbagai permasalahan yang ada pada masing-masing model desa yang telah dirumuskan. Serta pada potensi desa. Otonomi desa menuntut pemerintah desa untuk menggali potensi desa menjadi sektor unggulan (Yudartha, 2017, p. 65). Melakukan identifikasi terhadap berbagai potensi yang dimiliki desa, seperti Potensi Keanekaragaman endemik bernilai tinggi, potensi pariwisata, potensi perikanan dan kelautan, potensi industri, potensi perdagangan, potensi pertanian dan perkebunan, potensi kehutanan, potensi peternakan, potensi pertambangan dan energi, potensi usaha jasa, dan lain-lain. Hasil penelitian Achsin et al., (2016, p. 51) misalnya, menunjukkan, data profil desa dan kelurahan di Sulawesi Selatan sudah tersedia, namun belum lengkap dan akuntabel sehingga belum didayagunakan dan belum dapat berfungsi sebagai sumber informasi potensi desa dan kelurahan yang diharapkan dapat menjadi data 
Tabel 1.

Rumusan Instrumen Penilaian Desa

\begin{tabular}{|c|c|c|c|c|c|c|c|}
\hline \multirow[t]{2}{*}{ No. } & \multirow[t]{2}{*}{ Kriteria } & \multicolumn{3}{|c|}{ Parameter } & \multicolumn{3}{|c|}{$\begin{array}{c}\text { Penilian Kriteria } \\
\text { dan Parameter } \\
\text { (Rata-rata) }\end{array}$} \\
\hline & & a & $\mathrm{b}$ & C & a & $b$ & C \\
\hline 1. & $\begin{array}{l}\text { Kawasan Desa } \\
\text { Unit Administratif } \\
\text { Desa }\end{array}$ & - & - & - & - & - & - \\
\hline \multirow{8}{*}{2.} & $\begin{array}{l}\text { Infrastruktur } \\
\text { Prasarana Dasar } \\
\text { Jaringan Air Bersih }\end{array}$ & $\begin{array}{l}\text { Pelayanan terhadap } \\
\text { Luas Kawasan ku- } \\
\text { rang dari (<) } 25 \%\end{array}$ & $\begin{array}{l}\text { Pelayanan terha- } \\
\text { dap Luas Kawasan } \\
\text { antara } 25 \% \text { - } 50 \%\end{array}$ & $\begin{array}{l}\text { Pelayanan terhadap } \\
\text { Luas Kawasan lebih } \\
\text { dari (>) } 50 \%\end{array}$ & & & \\
\hline & Jaringan Listrik & $\begin{array}{l}\text { Pelayanan terhadap } \\
\text { Luas Kawasan ku- } \\
\text { rang dari }(<) 25 \%\end{array}$ & $\begin{array}{l}\text { Pelayanan terha- } \\
\text { dap Luas Kawasan } \\
\text { antara } 25 \% \text { - } 50 \%\end{array}$ & $\begin{array}{l}\text { Pelayanan terhadap } \\
\text { Luas Kawasan lebih } \\
\text { dari (>) 50\% }\end{array}$ & & & \\
\hline & Jaringan Irigasi & $\begin{array}{l}\text { Pelayanan terhadap } \\
\text { Luas Kawasan ku- } \\
\text { rang dari (<) } 25 \%\end{array}$ & $\begin{array}{l}\text { Pelayanan terha- } \\
\text { dap Luas Kawasan } \\
\text { antara } 25 \% \text { - } 50 \%\end{array}$ & $\begin{array}{l}\text { Pelayanan terhadap } \\
\text { Luas Kawasan lebih } \\
\text { dari (>) 50\% }\end{array}$ & & & \\
\hline & $\begin{array}{l}\text { Sarana } \\
\text { Sarana Ekonomi }\end{array}$ & $\begin{array}{l}\text { Pelayanan terhadap } \\
\text { Luas Kawasan ku- } \\
\text { rang dari (<) } 25 \%\end{array}$ & $\begin{array}{l}\text { Pelayanan terha- } \\
\text { dap Luas Kawasan } \\
\text { antara } 25 \% \text { - } 50 \%\end{array}$ & $\begin{array}{l}\text { Pelayanan terhadap } \\
\text { Luas Kawasan lebih } \\
\text { dari (>) 50\% }\end{array}$ & & & \\
\hline & Sarana Industri & $\begin{array}{l}\text { Pelayanan terhadap } \\
\text { Luas Kawasan ku- } \\
\text { rang dari (<) } 25 \%\end{array}$ & $\begin{array}{l}\text { Pelayanan terha- } \\
\text { dap Luas Kawasan } \\
\text { antara } 25 \% \text { - } 50 \%\end{array}$ & $\begin{array}{l}\text { Pelayanan terhadap } \\
\text { Luas Kawasan lebih } \\
\text { dari (>) 50\% }\end{array}$ & & & \\
\hline & Sarana Kesehatan & $\begin{array}{l}\text { Pelayanan terhadap } \\
\text { Luas Kawasan ku- } \\
\text { rang dari (<) } 25 \%\end{array}$ & $\begin{array}{l}\text { Pelayanan terha- } \\
\text { dap Luas Kawasan } \\
\text { antara } 25 \% \text { - } 50 \%\end{array}$ & $\begin{array}{l}\text { Pelayanan terhadap } \\
\text { Luas Kawasan lebih } \\
\text { dari (>) 50\% }\end{array}$ & $\begin{array}{l}\text { Buruk } \\
\text { (BR) }\end{array}$ & $\begin{array}{l}\text { Cukup } \\
\text { (CK) }\end{array}$ & $\begin{array}{l}\text { Baik } \\
\text { (BK) }\end{array}$ \\
\hline & Sarana Pendidikan & $\begin{array}{l}\text { Pelayanan terhadap } \\
\text { Luas Kawasan ku- } \\
\text { rang dari (<) } 25 \%\end{array}$ & $\begin{array}{l}\text { Pelayanan terha- } \\
\text { dap Luas Kawasan } \\
\text { antara } 25 \% \text { - } 50 \%\end{array}$ & $\begin{array}{l}\text { Pelayanan terhadap } \\
\text { Luas Kawasan lebih } \\
\text { dari (>) 50\% }\end{array}$ & & & \\
\hline & Sarana Transportasi & $\begin{array}{l}\text { Pelayanan terhadap } \\
\text { Luas Kawasan ku- } \\
\text { rang dari (<) } 25 \%\end{array}$ & $\begin{array}{l}\text { Pelayanan terha- } \\
\text { dap Luas Kawasan } \\
\text { antara } 25 \% \text { - } 50 \%\end{array}$ & $\begin{array}{l}\text { Pelayanan terhadap } \\
\text { Luas Kawasan lebih } \\
\text { dari (>) 50\% }\end{array}$ & & & \\
\hline \multirow{3}{*}{3.} & $\begin{array}{l}\text { Kehidupan Mayarakat } \\
\text { Perekonomian Masy. } \\
\text { Keluarga Pra Sejahtera }\end{array}$ & $\begin{array}{l}\text { Jumlah Penduduk } \\
\text { Miskin lebih dari (>) } \\
50 \%\end{array}$ & $\begin{array}{l}\text { Jumlah Penduduk } \\
\text { Miskin antara 25\% } \\
\text { - } 50 \%\end{array}$ & $\begin{array}{l}\text { Jumlah Penduduk } \\
\text { Miskin kurang dari } \\
\text { (<) } 25 \%\end{array}$ & & & \\
\hline & $\begin{array}{l}\text { Pendidikan Masy. } \\
\text { Pendidikan Di Bawah } \\
9 \text { Thn. }\end{array}$ & $\begin{array}{l}\text { Jumlah Penduduk } \\
\text { Miskin kurang dari } \\
\text { (<) } 25 \%\end{array}$ & $\begin{array}{l}\text { Tingkat Pendidikan } \\
\text { Penduduk (<) SMP } \\
\text { antara } 25 \%-50 \%\end{array}$ & $\begin{array}{l}\text { Tingkat Pendidikan } \\
\text { Penduduk }(<) \text { SMP } \\
\text { kurang dari }(<) 25 \%\end{array}$ & $\begin{array}{l}\text { Buruk } \\
\text { (BR) }\end{array}$ & $\begin{array}{l}\text { Cukup } \\
\text { (CK) }\end{array}$ & $\begin{array}{l}\text { Baik } \\
\text { (BK) }\end{array}$ \\
\hline & $\begin{array}{l}\text { Produktivitas Masy. } \\
\text { Penganggur Usia } \\
\text { Produktif }\end{array}$ & $\begin{array}{l}\text { Penduduk Men- } \\
\text { ganggur lebih dari } \\
\text { (>) } 50 \%\end{array}$ & $\begin{array}{l}\text { Penduduk Men- } \\
\text { ganggur antara } 25 \% \\
-50 \%\end{array}$ & $\begin{array}{l}\text { Penduduk Mengang- } \\
\text { gur kurang dari }(<) \\
25 \%\end{array}$ & & & \\
\hline
\end{tabular}

Sumber: Kementerian Negara Pembangunan Daerah Tertinggal RI (2018).

dasar dalam perencanaan pembangunan.

Identifikasi Karakteristik Daerah

(Permasalahan dan Potensi). Melakukan identifikasi terhadap karakteristik daerah, baik permasalahan maupun potensi daerah, sebagai bagian dari identifikasi penanganan masing-masing model desa yang telah dirumuskan. Jika detail dan akurat hasil identifikasi karakteristik permasalahan dan potensi suatu daerah, maka akan menghasilkan suatu skenario indikasi penanganan yang valid dan sesuai dengan aspirasi dan kebutuhan suatu daerah. Sebaliknya, jika bias dan tidak akurat hasil karakteristik permasalahan dan potensi suatu daerah, maka akan menghasilkan suatu skenario 
Tabel 2.

Rumusan Berbagai Kemungkinan Model Desa Berdasarkan Kriteria dan Parameternya.

\begin{tabular}{|c|c|c|c|c|c|c|c|c|c|c|c|c|c|c|}
\hline \multirow[b]{2}{*}{ No. } & \multirow{2}{*}{$\begin{array}{l}\text { Klasifikasi } \\
\text { Desa }\end{array}$} & \multicolumn{13}{|c|}{ Model Desa } \\
\hline & & A & B & $\mathrm{C}$ & $\mathrm{D}$ & $E$ & $\mathrm{~F}$ & G & $\mathrm{H}$ & 1 & J & K & $\mathrm{L}$ & Dst. \\
\hline 1 & Prasarana Dasar Wilayah Desa & $\mathrm{BR}$ & BK & CK & CK & BK & BK & $\mathrm{BR}$ & CK & BK & CK & $B R$ & $\mathrm{BR}$ & \\
\hline 2 & Sarana Desa & $\mathrm{CK}$ & CK & $B R$ & BK & $B R$ & CK & $B R$ & CK & BK & CK & $B R$ & BR & \\
\hline 3 & Kehidupan Masyarakat Desa & BK & $\mathrm{BR}$ & BK & BR & BR & CK & BR & CK & BK & CK & BK & CK & \\
\hline
\end{tabular}

Keterangan: $\mathrm{BR}=$ Buruk, $\mathrm{CK}=$ Cukup, $\mathrm{BK}=$ Baik.

Acuan: Kementerian Negara Pembangunan Daerah Tertinggal RI (2018).

indikasi pembinaan yang tidak valid dan tidak sesuai dengan aspirasi dan kebutuhan suatu daerah.

\section{Kebijakan (Skenario) Pembinaan Desa}

Ada beberapa indikasi kebijakan bentuk penanganan desa. Indikasi tersebut adalah, pertama, indikasi bentuk penanganan penyelesaian masalah. Untuk mengatasi permasalahan desa-desa (berdasarkan hasil identifikasi permasalahan yang telah dilakukan terlebih dahulu), diindikasikan beberapa bentuk program penanganan desa. Misalnya, program penyediaan prasarana dasar wilayah (pemerataan ketersediaan air bersih, pemerataan ketersediaan listrik, dan pemerataan ketersediaan irigasi), serta program penyediaan sarana wilayah (penyediaan sarana ekonomi), seperti pasar, pertokoan, perkantoran, dan pedagang kaki lima.

1) Program Peningkatan Perekonomian Masyarakat.

Pengelolaan potensi ekonomi rakyat dan sumberdaya alam secara optimal bertujuan untuk meningkatkan taraf hidup dan kesejahteraan masyarakat yang ditunjukan oleh peningkatan pendapatan dan daya beli masyarakat. Prioritas pembangunan ini diarahkan untuk peningkatan produktivitas dan kualitas pertanian dan industri yang menghasilkan komoditas unggulan daerah.

2) Program Peningkatan Pendidikan Masyarakat. Kegiatan prioritas pendidikan adalah: Penyediaan dan peningkatan kualitas sarana dan prasarana pendidikan, yaitu: Pendirian sekolah dan fasilitas sarana, Perbaikan bangunan sekolah, dan Pengadaan buku pelajaran dan alat peraga; Peningkatan kualitas dan kualifikasi guru; Penuntasan Wajib Belajar 9 tahun baik melalui pendidikan formal dan pendidikan luar sekolah; serta Mempercepat pemberantasan buta aksara dengan menyelenggarakan pendidikan keaksaraan fungsional.
3)

Program Peningkatan
Masyarakat.
Dalam rangka meningkatkan masyarakat, pembangunan produktivitas ketenagakerjaan dilaksanakan melalui kegiatan melalui kegiatan prioritas perluasan dan pengembangan kesempatan kerja, peningkatan kualitas dan produktivitas tenaga kerja, serta perlindungan tenaga kerja.

Kedua, indikasi bentuk penanganan pengembangan potensi kawasan. Dalam rangka pengembangan potensi yang dimiliki suatu kawasan (berdasarkan potensi yang telah diidentifikasi terdahulu), maka ada beberapa indikasi program penanganan yang dapat dilakukan. Misalnya, program pengembangan potensi pariwisata, seperti mendorong investasi swasta dan asing, aktif dan kreatif dalam perencanaan pariwisata, penyediaan sarana akomodasi, dan memaksimalkan promosi.

Adapun program pengembangan potensi kehutanan seperti: penyediaan sarana akses untuk distribusi logging, penyediaan sarana industri pengolahan, pengendalian bencana kebakaran hutan, pengendalian pencurian kayu (illegal logging), pemberdayaan lembaga dan organisasi kehutanan, dan pengendalian dampak lingkungan; program pengembangan potensi peternakan seperti: pengendalian distribusi dan harga pakan ternak, penyediaan akses pemasaran dan distribusi hasil peternakan, pemberdayaan lembaga dan organisasi peternak, revitalisasi lembaga koperasi, dan pengembangan pusat layanan informasi peternakan.

Selanjtunya, program pengembangan potensi perikanan air tawar seperti: pengendalian distribusi dan harga pakan ikan, penyediaan akses pemasaran dan distribusi hasil perikanan, pemberdayaan lembaga dan organisasi nelayan dan petani tambak, revitalisasi lembaga koperasi, dan pengembangan pusat layanan informasi perikanan. Program pengembangan potensi pertambangan dan energi seperti mendorong investasi untuk eksplorasi dan 
eksploitasi, penyediaan sarana akses distribusi hasil pertimbangan dan energi, pengendalian aktivitas eksploitasi, dan pengendalian dampak lingkungan.

\section{Identifikasi Pengelolaan Pembinaan Desa.}

Setelah melakukan identifikasi bentuk pembinaan untuk desa-desa, selanjutnya perlu dilakukan identifikasi pengelolaan pembinaannya, termasuk di dalamnya instansi yang akan melakukan pembinaan tersebut. Sistem pengelolaan pembinaan desa-desa dalam upaya menyelesaikan permasalahan yang ada serta memicu pengembangan lebih lanjut kawasan desa teridentifikasi perlu didasarkan pada potensi yang dimiliki masing-masing desa dan dapat dijabarkan lebih lanjut.

Pertama, penanganan pembangunan kewenangan pemerintah kabupaten. Sesuai dengan UU Pemerintahan Daerah, maka pelaksanaan pembangunan di daerah merupakan kewenangan dan tanggung jawab pemerintah daerah, khususnya pemerintah kabupaten. Pelaksanaan pembangunan desa juga menjadi bagian dari tanggung jawab dan kewenangan tersebut, dalam rangka mengemban program pembangunan nasional pemerataan pembangunan dan mengejar ketertinggalan pembangunan di daerah. Dalam konteks pembangunan desa, maka pemerintah kabupaten memiliki tugas dan tanggung jawab untuk melaksanakan bentuk penanganan pembangunan. Pelaksanaan penanganan pembangunan dilaksanakan oleh Pemerintah Kabupaten dengan mengoptimalkan dinas, badan, dan instansi dalam Struktur Pemerintah Kabupaten sesuai dengan tugas, pokok, dan fungsinya masing-masing (Mubyarto, 2006, p. 113).

Selanjutnya, pemerintah provinsi memiliki fungsi dan peran sebagai koordinator dan fasilitator dalam proses pembangunan di daerah. Adapun pemerintah pusat memiliki fungsi sebagai pembuat kebijakan dalam proses pembangunan nasional. Pemerintah Pusat menjadi penentu arah dan kebijakan pembangunan, di mana maksud dan tujuannya di antaranya adalah menjadikan pelaksanaan pembangunan nasional satu kesatuan yang integral (Tomasoa, 2017, p. 76). Hasil kebijakan yang dibuat selanjutnya didelegasikan kepada pemerintah di daerah untuk selanjutnya diterjemahkan sesuai dengan kebutuhan dan karakteristik masing-masing.

Kedua, sumber pendanaan. Pembiayaan untuk melaksanakan pembangunan kawasan desa-desa dapat bersumber dari 4 pembiayaan. Dari Anggaran Pendapatan dan Belanja Negara (APBN). Tujuan pemberian dana desa ini adalah untuk mendanai penyelenggaraan pemerintahan, pelaksanaan pembangunan, dan pemberdayaan masyarakat desa.
Namun, dalam pelaksanaan penggunaan dana desa masih dirasakan belum efektif dikarenakan belum memadainya kapasitas dan kapabilitas pemerintah desa dan belum terlibatnya peran serta masyarakat secara aktif dalam pengelolaan dana desa (Aziz, 2016, p. 88).

Pembangunan Desa pada hakikatnya merupakan tanggung jawab dan kewenanganan pemerintah daerah, untuk itu pemerintah daerah wajib memprioritaskan pengalokasian dananya untuk mengatasi ketimpangan daerahnya baik melalui APBD Provinsi, yaitu berupa subsidi daerah bawahan (tugas pembantuan); maupun APBD Kabupaten, yaitu berupa pembantuan ke desa.

Selanjutnya, Dana Alokasi Khusus dapat diprioritaskan untuk mengatasi kesenjangan pembangunan di desa. Kewenanganan pengaturan dan kewenanganan alokasi DAK berada di tangan Pemerintah Daerah. Penggunaan Alokasi Danas Desa (ADD) disalurkan untuk pembangunan perdesaan, pengembangan masyarakat, dan meningkatkan pendapatan. Namun, penggunaan ADD masih menemui sejumlah permasalahan dalam perencanaan, pelaksanaan, kualitas pelaporan, dan lemahnya kelembagaan desa serta koordinasi dengan pemerintah daerah kota/kabupaten (Abidin, 2015, p. 69).

Selanjutnya sumber pendanaan berbsumber dari dana swasta dan masyarakat. Untuk daerah yang memiliki potensi sumber daya alam besar, sumber dana dapat diperoleh dari dana kapitalisasi sumber daya alam dan investasi dunia usaha/swasta. Peran masyarakat dan swasta pada beberapa daerah yang telah berkembang memiliki kontribusi yang cukup signifikan dalam pembangunan suatu daerah.

Sumber pendanaan juga bisa dari dana penerimaan lain yang sah. Dana penerimaan lain yang sah merupakan dana-dana yang belum termasuk di atas dan dapat dijadikan alokasi untuk pembangunan desa, baik yang dikelola langsung oleh Pemerintah Daerah, Lembaga non pemerintah (NGO) maupun lembaga pemerintah, serta oleh masyarakat.

Ketiga, langkah penanganan pembangunan untuk pembinaan desa perlu mencakup hal-hal. Pada tahap awal adalah perencanaan (planning). Perencanaan disusun secara komprehensif dan konsisten serta mengacu kepada konsep bottom-up planning, di mana keputusan yang diambil didapat dari aspirasi bawah. Semua masukan perencanaan harus dapat mengakomodasikan aspirasi masyarakat secara demokratis, melalui keterlibatan berbagai kelembagaan sosial politik dan sosial ekonomi, perguruan tinggi, LSM, tokoh masyarakat yang dapat dilaksanakan melalui forum dialog, dan hasilnya kemudian dikaji lebih lanjut melalui forum diskusi pemerintah daerah dan DPRD.

Setelah perencanaan kemudian pelaksanaan 
(execution). Pelaksanaan pembangunan daerah sebagai upaya penyelesaian permasalahan ketertinggalan dan keterpencilan didesentralisasikan kepada pemerintah kabupaten/ kota sesuai dengan UU Pemerintahan Daerah. Dalam paradigma baru yaitu penerapan konsep good governance dalam pembangunan, masyarakat ditempatkan sebagai pelaku utama dan kesejajaran peran antara pemerintah, masyarakat dan pelaku bisnis dijunjung tinggi. Dalam rangka mewujudkan kesejajaran masyarakat, dilakukan pemberdayaan dengan memberikan ruang untuk meningkatkan partisipasi dalam setiap pengambilan keputusan.

Langkah penanganan pembangunan untuk pembinaan desa dilakukan melalui pengendalian/ pengawasan (monitoring). Pengendalian/ pengawasan pada hakikatnya perlu dan harus dilakukan oleh setiap penyandang dana dalam kegiatan pembangunan. Dalam hal ini, selayaknya pengendalian dilakukan oleh pemerintah pusat, pemerintah provinsi dan internal pemerintah kabupaten itu sendiri. Bahkan dalam era transparansi, masyarakat dan pihak swasta juga dapat terlibat dalam pengendalian pembangunan. Pemerintah kabupaten dengan DPRD setempat dapat menyiapkan wadah bagi masyarakat dan pihak swasta untuk dapat memberikan masukan/informasi hasil pengawasan, agar dapat ditindaklanjuti oleh pemerintah.

Terakhir adalah evaluasi (evaluation). Pada hakikatnya evaluasi berjalan beriringan dengan kegiatan monitoring (monev-monitoring evaluation). Sehingga pada dasarnya seperti juga pada monitoring, evaluasi seharusnya dilakukan oleh setiap penyandang dana pembangunan. Terutama untuk program pembangunan yang berkelanjutan dan berjangka panjang, evaluasi memiliki arti strategis untuk mereview arah, manfaat dan pencapaian hasil yang telah dilaksanakan. Dalam paradigma baru, evaluasi pelaksanaan pembangunan dapat dilakukan oleh pemerintah bersama-sama dengan masyarakat. Kehadiran berbagai potensi kelembagaan di luar birokrasi pemerintah dapat dipesankan untuk menilai keberhasilan pelaksanaan program pembangunan dengan difasilitasi oleh instansi pemerintah.

\section{E. Strategi Prioritas Pembinaan Desa}

Strategi prioritas pembinaan desa bisa dilakukan pertama, rumusan kebijakan prioritas penanganan permasalahan. Mengingat besarnya permasalahan yangharus dihadapi untuk menangani desa, maka perlu dilakukan strategi pelaksanaan berupa identifikasi prioritas penanganan. Strategi prioritas penanganan dirumuskan dengan urutan desa yang paling buruk, berurut sampai dengan desa yang paling tidak buruk. Dalam merumuskan strategi prioritas penanganan, dilakukan dengan mengacu pada rumusan kemungkinan model desa yang telah ditetapkan sebelumnya. Dengan mengacu pada kemungkinan model tersebut, maka upaya mengurutkan prioritas penanganan lebih terstruktur dan terprogram.

Kedua, rumusan kebijakan prioritas penanganan pengembangan potensi daerah merupakan suatu bentukpenanganan pembangunan yang disesuaikan dengan potensi daerah yang bersifat spesifik. Penanganan Pengembangan Potensi Daerah merupakan salah satu bentuk pembangunan yang perlu dilakukan dalam rangka pengembangan desa-desa di suatu daerah, yaitu: (1) Pengembangan Potensi Unggulan, (2) Pengembangan Potensi Berbasis Kemasyarakatan, dan (3) Pengembangan Potensi Kecil dan Menengah (Marbun, 1977, p. 61).

Adapun Strategi Prioritas Penanganan yang dijelaskan di atas dapat digambarkan secara skematis pada gambar 1 di bawah ini:

Ketiga, terkait dengan strategi prioritas pembinaan, yang perlu ditekankan selanjutnya adalah masalah keberlanjutan program (program sustainibility). Besarnya permasalahan yang dihadapi untuk menangani desa-desa tidak akan terselesaikan seluruhnya dalam jangka waktu yang singkat (pendek). Satu periode pemerintahan yang berlangsung selama 5 (lima) tahun tidak akan mampu menyelesaikan permasalahan yang ada. Untuk itu perlu adanya komitmen dan dukungan adanya keberlangsungan program pembinaan desadesa secara sistematis dan struktural.

\section{F. Penyajian Hasil Identifikasi Model Desa}

Dalam penyajian hasil identifikasi model desa bisa dilakukan, pertama, penyajian berdasarkan daftar desa dengan model desa yang telah dilakukan sebelumnya, serta penyajian hasil keluaran kajian berupa matriks penanganan desa yang diidentifikasi berdasarkan permasalahan yang dihadapi setiap desa.

Selain itu, berdasarkan Hasil Peliputan Data dan Informasi yang dilakukan melalui penjajakan questionnaire yang telah dilakukan pada tahapan survey sebelumnya, perlu juga disajikan hasil keluaran kajian berupa matriks penanganan pengembangan potensi daerah yang diidentifikasi berdasarkan karakteristik potensi yang dimiliki setiap daerah.

Kedua, legalisasi hasil identifikasi. Oleh karena banyak dan besarnya permasalahan yang perlu ditangani dalam pembangunan desa, maka penting adanya keberlangsungan dan keberlanjutan (sustainibility and continuity) program dengan komitmen dan dukungan politis terhadap kebijakan dan program penanganan desa. Terkait dengan masalah itu, legalisasi hasil identifikasi dalam bentuk peraturan daerah penting untuk dilakukan. 


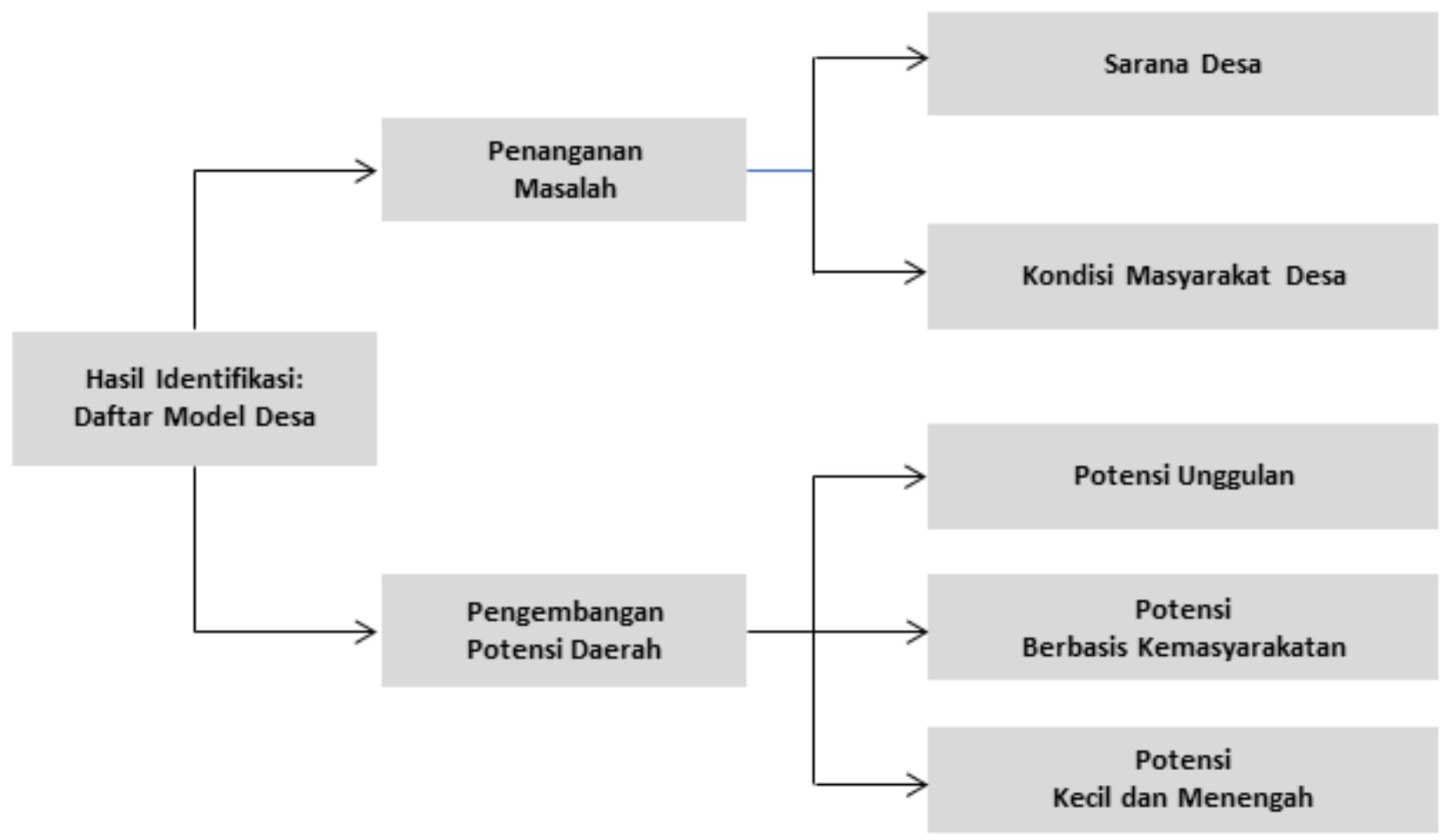

Gambar 1

Penanganan Pengembangan Potensi Daerah

Melalui peraturan daerah, hasil identifikasi akan menjadi program pembangunan yang secara berkelanjutan akan diemban pemerintah daerah dalam kebijakan penanganan desa.

\section{KESIMPULAN}

Model desa yang telah dirumuskan dalam kajian ini dimulai dengan identifikasi model desa, identifikasi permasalahan dan potensi desa, hingga skenario dan strategi prioritas pembinaan desa. Ke depan, Pemerintah khsususnya Ditjen Bina Pemdes Kemendagri perlu mengenalkan konsep model desa ini yang didasarkan pada potensi dan permasalahan yang dihadapi desa. Sebab, apabila kebijakan penentuan model desa semata-mata mengacu pada tipologi desa dengan merujuk pada karakteristik desa, maka pembinaannya pun akan bersifat umum. Model-model desa yang dibangun dalam kajian ini lebih bersifat komprehensif karena melalui studi identifikasi desa-desa, penetapan kawasan secara jelas dan definitif, serta tata cara peliputan data dan informasi. Selain itu, model desa ini ditetapkan berdasarkan kriteria kewenangan desa, prasarana dasar, sarana, dan kondisi kehidupan masyarakat desa, sehingga kebijakan pembinaan pun bisa ditetapkan secara lebih tepat. Penetapan hasil identifikasi model-model desa perlu menjadi kebijakan dan program pembangunan secara berkelanjutan oleh Pemerintah Daerah dalam kebijakan penanganan desa-desa di wilayahnya.

\section{UCAPAN TERIMA KASIH}

Terima kasih kepada Kepala Badan Penelitian dan Pengembangan Daerah Provinsi Papua yang memberikan dukungan terhadap pelaksaan kajian ini.

\section{Daftar Pustaka}

Abidin, M. Z. (2015). Tinjauan atas Pelaksanaan Keuangan Desa dalam Mendukung Kebijakan Dana Desa. Jurnal Ekonomi Dan Kebijakan Publik, 6(1), 61-76. https://doi.org/10.22212/ JEKP.V6I1.156

Achsin, S. N., Cangara, H., \& Unde, A. A. (2016). Profil Desa dan Kelurahan sebagai Sumber Informasi: Studi Evaluasi tentang Penyediaan Informasi Potensi Desa dan Kelurahan di Sulawesi Selatan oleh Badan Pemberdayaan Masyarakat Pemerintahan Desa dan Kelurahan (BPMPDK) Provinsi Sulawesi Selatan. KAREBA: Jurnal Ilmu Komunikasi, 4(4), 449-467. https://doi. org/10.31947/KJIK.V4I4.649

Aditiawati, P., Astuti, D. I., Suantika, G., \& Simatupang, T. M. (2016). Pengembangan Potensi Lokal di Desa Panawangan Sebagai Model Desa Vokasi dalam Pemberdayaan Masyarakat dan Peningkatan Ketahanan Pangan Nasional. Jurnal Sosioteknologi, 15(1), 59-67. https:// doi.org/10.5614/sostek.itbj.2016.15.1.6

Aminah, S., \& Sutanto, H. P. (2018). Analisis Tingkat Kapasitas Aparatur Pemerintah 
Tabel 3.

Penilaian dan Model Desa Kabupaten ..... Provinsi .....

\begin{tabular}{|c|c|c|c|c|c|c|c|c|c|c|c|c|c|}
\hline \multirow{3}{*}{ No. } & \multirow{3}{*}{ Kecamatan } & \multicolumn{11}{|c|}{ Permasalahan } & \multirow{3}{*}{$\begin{array}{c}\text { Model } \\
\text { Desa }\end{array}$} \\
\hline & & \multicolumn{3}{|c|}{ PPD } & \multicolumn{5}{|c|}{ PSW } & \multicolumn{3}{|c|}{ PKM } & \\
\hline & & $A B$ & $\mathrm{~L}$ & I & SE & $\mathrm{SI}$ & SK & SP & ST & PKS & PB9 & PUP & \\
\hline
\end{tabular}

1. Kecamatan .....

Desa .....

Desa .......

Desa .......

2. Kecamatan .....

Desa ....

Desa ....

Desa ....

3. Dst

Catatan: Penyajian ini mengacu pada hasil Tabel 1 (Instrumen Penilaian Desa). Keterangan:

\begin{tabular}{lll}
\hline PPD = Penilaian Prasarana Dasar PPD, PSW, PKM diisi & SE & Sarana Ekonomi \\
dengan penilian: BK = Baik, CK =Cukup, arau BR = Buruk & SI & $=$ Sarana Industri \\
PSW = Penilaian Sarana Wilayah & SK & $=$ Sarana Kesehatan \\
PKM = Penilaian kehidupan Masyarakat & SP & $=$ Sarana Pendidikan \\
AB = Air Bersih & ST & $=$ Sarana Transportasi \\
$\mathrm{L}=$ Listrik & PKS & $=$ Pra Keluarga Sejahtera \\
$\mathrm{I}=$ Irigasi & PB9 & $=$ Pendidikan Di Bawah Tahun \\
& PUP & $=$ Penganggur Usia Produktif
\end{tabular}

- PPD, PSW, PKM diisi dengan penilian:: BK = Baik, CK = Cukup, arau BR = Buruk

- Model Desa: Model Desa A, B, C, dst. (selajutnya dikelompokkan)

Tabel 4.

Penanganan/Pembinaan Desa Kabupaten ..... Provinsi ......

\begin{tabular}{|c|c|c|c|c|c|c|c|c|c|c|c|c|c|}
\hline \multirow[t]{3}{*}{ No. } & \multirow[t]{3}{*}{ Kecamatan } & \multirow{3}{*}{$\begin{array}{c}\text { Model } \\
\text { Desa }\end{array}$} & \multicolumn{11}{|c|}{$\begin{array}{l}\text { Indikasi Penanganan Untuk Penyelesaian Masalah } \\
\text { (Disesuaikan dengan Kebutuhan Lokasi Berdasarkan Kuesioner) }\end{array}$} \\
\hline & & & \multicolumn{3}{|c|}{ PPKPD } & \multicolumn{5}{|c|}{ PPKSW } & \multicolumn{3}{|c|}{ PPMSEM } \\
\hline & & & $A B$ & L & I & SE & SI & SK & SP & ST & PPPM1 & PPPM2 & PPM3 \\
\hline
\end{tabular}

1. Kecamatan

$\begin{array}{cc}\cdots \cdots & \cdots \cdots \\ \text { Desa } \ldots . . . & \cdots \cdots \\ \text { Desa } \ldots \ldots & \cdots \cdots \\ \text { Desa } \ldots \ldots & \end{array}$

2. Kecamatan

$\begin{array}{cc}\text {..... } & \ldots \ldots . \\ \text { Desa .... } & \ldots \ldots . \\ \text { Desa ..... } & \ldots \ldots . . \\ \text { Desa } . . . & \end{array}$

Desa ....

3. Dst ..............

Catatan: Penyajian ini mengacu pada hasil Tabel 2.

Keterangan:

PPKPD = Program Pemerataan Ketersediaan Prasarana Dasar

PPKSW = Program pemerataan Ketersedaiaan Sarana Wilayah

PPMSEM = Program Peningkatan Masalah Sosial Ekonomi Masyarakat

PPPM1 = Program Peningkatan Perekonomian Masyarakat

PPPM2 = Program Peningkatan Pendidikan Masyarakat

PPPM3 = Program Peningkatan Produktivitas Masyarakat

$\mathrm{AB}=$ Air Bersih

$\mathrm{L} \quad=$ Listrik

I = Irigasi

SE = Sarana Ekonomi

SI = Sarana Industri

SK = Sarana Kesehatan

$\mathrm{SP}=$ Sarana Pendidikan

ST = Sarana Transportasi

PKS = Pra Keluarga Sejahtera

PB9 = Pendidikan Di Bawah 9 Tahun

PUP = Penganggur Usia Produktif

- Diberi ceklis $(\sqrt{ })$ jika hasil penilaian desa adalah BR (Buruk). 
Desa di Kabupaten Bogor. Matra Pembaruan, 2(3), 149-160. https://doi.org/10.21787/ mp.2.3.2018.149-160

Aziz, N. L. L. (2016). Otonomi Desa dan Efektivitas Dana Desa. Jurnal Penelitian Politik, 13(2), 193211. https://doi.org/10.14203/JPP.V13I2.575

Goldsmtih, A. A., \& Blustain, H. S. (1980). Local Organization and Participation in Integrated Rural Development in Jamaica (Issue No. 3). Cornell University.

Hasniati. (2016). Model Akuntabilitas Pengelolaan Dana Desa . JAKPP (Jurnal Analisis Kebijakan \& Pelayanan Publik). http://journal.unhas.ac.id/ index.php/jakpp/article/view/1519

Hilman, Y. A., \& Nimasari, E. P. (2018). Model Program Pemberdayaan Masyarakat Desa Berbasis Komunitas. ARISTO, 6(1), 45-67. https://doi.org/10.24269/ars.v6i1.778

Marbun, B. N. (1977). Proses Pembangunan Desa, Menyongsong Tahun 2000: Pandangan Seorang Anak Desa. Erlangga.

Misra, R. P. (2016). Rural Development: National Policies and Experiences. Maruzen Asia.

Mubyarto. (2006). Strategi Pembangunan Pedesaan. Pusat Penelitian Pembangunan Pedesaan dan Kawasan, UGM.

Pakaya, J. (2016). Pemberian Kewenangan pada Desa dalam Konteks Otonomi Daerah. Jurnal Legislasi Indonesia, 13(1), 73-84. http://ejurnal.peraturan.go.id/index.php/jli/article/ view/143
Rochman, N. (2017). Model Pengembangan Desa Wisata Berbasis Pemberdayaan Masyarakat. EQUILIBRIA PENDIDIKAN : Jurnal Ilmiah Pendidikan Ekonomi, 1(1), 59-70. https://doi. org/10.26877/ep.v1i1.1831

Siagian, S. P. (2003). Organisasi, Kepemimpinan dan Perilaku Administrasi. Gunung Agung.

Subekti, T., \& Damayanti, R. (2019). Penerapan Model Smart Village dalam Pengembangan Desa Wisata: Studi pada Desa Wisata Boon Pring Sanankerto Turen Kabupaten Malang. Journal of Public Administration and Local Governance, 3(1), 18-28. https://doi.org/10.31002/jpalg. v3i1.1358

Sugianto, , Muchammad, Djana, A., \& Ismail, A. (2016). Pengembangan Desa Wisata Berbasis Kemitraan di Desa Koloray Kabupaten Pulau Morotai. Jurnal Sosiologi USK, Media Pemikiran \& Aplikasi. http://jurnal.unsyiah.ac.id/JSU/ article/view/6894

Tomasoa, J. (2017). Membangun Sambil Melayani Pedesaan. Salatiga UKSW.

Uphoff, N. T., Cohen, J. M., \& Goldsmith, A. A. (1979). Feasibility And Application of Rural Development Participation: A State-of-the-Art Paper. Cornell University.

Yudartha, I. P. D. (2017). Alternatif Kebijakan Pertanian dalam Menghadapi Otonomi Desa di Kabupaten Tabanan. Matra Pembaruan, 1(2), 65-74. https://doi.org/10.21787/ mp.1.2.2017.65-74 